\title{
S Research Square

\section{Evaluating Potential of Traditional and Newer Periphytic Diatom Metrices for Deciphering The Impact of Organic Pollution on Residing Aquatic Biofilms}

Lalit Kumar Pandey ( $\square$ lalitplantscience@gmail.com )

M J P Rohilkhand University Faculty of Applied Sciences

Harshita Gupta

Mahatma Jyotiba Phule Rohilkhand University

Elizabeth A. Bergey

Oklahoma Biological Survey

Aafiya Shameem

Mahatma Jyotiba Phule Rohilkhand University

\section{Sanjeev Kumar Maurya}

M J P Rohilkhand University Faculty of Applied Sciences

Virendra Kumar

M J P Rohilkhand University Faculty of Applied Sciences

Jyoti Chaubey

M J P Rohilkhand University Faculty of Applied Sciences

\section{Sudeeksha Negi}

M J P Rohilkhand University Faculty of Applied Sciences

Divyanshi Gupta

M J P Rohilkhand University Faculty of Applied Sciences

Mahima Gupta

M J P Rohilkhand University Faculty of Applied Sciences

Abhisekh Kumar

M J P Rohilkhand University Faculty of Applied Sciences

Shivangi Singh

M J P Rohilkhand University Faculty of Applied Sciences

\section{Sangeeta Sangeeta}

M J P Rohilkhand University Faculty of Applied Sciences 
Keywords: Diatoms, Emerging wastes, Deformities, Biomonitoring, Lipid bodies, Hazards

Posted Date: February 1st, 2022

DOI: https://doi.org/10.21203/rs.3.rs-1241041/v1

License: (c) (i) This work is licensed under a Creative Commons Attribution 4.0 International License. Read Full License 


\section{Abstract}

The present study examined impacts of organic contamination on periphytic biofilms at different sites near rivers using various traditional and newer diatom-based metrics, which is rarely tested under organic contamination. All examined sites were dominated by diatoms rather than green algae, which often dominate nutrient-rich sites. Biodiversity indices were higher at riverine and mass bathing sites than the kitchen waste site. Newer diatom metrics showed more promising results in terms identifying possible differences among sites. The three examined waste sites showed the dominance of motile forms, high percentages of unhealthy cells and enlarged lipid bodies in the community, indicating the contamination of nutrients and organic matter. A remarkable higher percentage of tube-dwelling forms at kitchen waste sites likely indicates the presence of organic contamination in the water. The percentage of deformed diatom frustules was low at all sites, indicating that organic contamination did not affect the morphology of diatom cells, but the occurrence of both cell shape and striae deformations at the RWS site might indicate slight metal contamination. Finally, we conclude that the combination of both traditional and newer diatom metrics in biomonitoring improves our understanding on the effects organic contamination in aquatic ecosystems.

\section{Introduction}

In India, the population is increasing day by day, which affects our waterbodies at an increasing rate (Paul, 2017; Dwivedi et al., 2018). Increasing population leads to rapid urbanization and large-scale industrialization in the riverine regions of fluvial ecosystems. Due to a combination of public negligence and oblivious governmental agencies, water pollution is a serious problem in India (Rai et al., 2013). All major rivers in the Ganga Plain in India face issues with pollution (Paul, 2017). Water pollution leads to various problems, including algal bloom formation, health hazards, aversion by tourists and death or impairment of aquatic fauna (Rai et al., 2013; Dwivedi et al., 2020).

Water quality assessment of waterbodies is usually done by sophisticated instruments that measure water chemistry, such as atomic absorption spectroscopy (AAS) and inductively coupled plasma (ICP). Generally, these instruments are costly, need highly skilled operators and involve tedious sample preparation (Wolska et al., 2007). Most importantly, these instruments provide information about the concentration of pollutants in the water at a single time point and are unable to inform about the effects of pollutants on the residing flora and fauna. For these reasons, incorporation of biomonitoring practices along with traditional methods get lot of attention worldwide for effective assessment of water quality (Wolska et al., 2007; Pandey et al., 2017).

In the light of the problems with using only chemical testing, biomonitoring practices are becoming increasingly used (Pandey et al., 2014). Biomonitoring relies on the status of residing biota in waterbodies and on this basis, provides much more effective information about the overall ecological status of waterbodies (Pandey et al., 2018a,b). In comparison to traditional chemical methods, 
biomonitoring shows more promise, as it is relatively easy, cheap and provides cause-effect relationships between pollutants and organisms (Stevenson et al., 2010; Morin et al., 2016; Pandey et al., 2017).

Various organisms (bacteria, fishes, micro and macroinvertebrates, aquatic plants etc.) are regularly used for aquatic biomonitoring (Bettinetti et al., 2012). Among these organisms, algae are perhaps the most used on a global basis. Reasons contributing to the widespread use of algae are their often cosmopolitan distribution (especially at the genus level) and autotrophic nature, short-life spans, easy availability and the generally low expense to collect and process samples. Among algae, diatoms are especially used for assessing the water quality worldwide. In addition to the advantages of using algae for biomonitoring, diatoms have several characteristics that make this group particularly useful, including their robust silica frustules, high biodiversity with a range of environmental tolerances and short life-span. This short lifespan makes them highly sensitive to many types of environmental and anthropogenic stresses, and changes in community composition or individual morphology can be preserved by their robust frustules for long time (McCormick and Cairns, 1994; Stevenson et al., 2010; Pandey et al., 2018) - a situation frequently useful in paleoecology.

Use of traditional diatom metrics (cell density, biovolume, species richness, Shannon index, relative abundance, etc.) for biomonitoring practices are in frequent use worldwide (Stevenson et al., 2010; Blanco et al., 2012; Pandey et al., 2017). However, the lack of precision of these metrics is becoming more apparent and newer diatom-based metrics (live diatom features such as, lipid bodies, alteration in protoplasmic content, nuclear anomalies, motility, life-forms, deformities and size reduction) are gaining interest. These newer diatom metrics are relatively less time consuming, less expensive, based on globally accepted protocols and require little taxonomic expertise (Pandey et al., 2017; Park et al., 2020) and can indicate sublethal effects.

This study examined the ecological health of various types of polluted sites in the Moradabad and Bareilly districts of Uttar Pradesh, India, using a combination of traditional (taxonomic) and newer diatom (non-taxonomic) metrics.

\section{Materials And Methods 2.1. Sampling sites}

Various organically polluted sites (mass bathing, kitchen wastes and riverine sites) near MJP Rohilkhand University and several sites from Moradabad were examined and periphytic diatom samples were collected. MJP Rohilkhand University men's and women's hostels were chosen for collecting mass bathing and kitchen waste area samples. Sampled sites on the Ram Ganga River in Moradabad (Figs. 1 and 2) include sites with a combination of point-source and more diffuse pollutant sources (Table 1). All the sites were selected on the basis of their long term legacy of organic pollution. 
Table 1

The selected waterbodies, their location and various human activities.

\begin{tabular}{|llll|}
\hline $\begin{array}{l}\text { Sites } \\
\text { Number }\end{array}$ & Name of Water bodies/Site & District & Activity \\
\hline $1-30$ & $\begin{array}{l}\text { Ram Ganga River (Nagfani, } \\
\text { Purana Dasma ghat and } \\
\text { Moradabad-Bareilly Flyover) }\end{array}$ & Moradabad & $\begin{array}{l}\text { Riverine activities (factory discharges, } \\
\text { household discharges, animal } \\
\text { discharges, ritual activities, farming } \\
\text { etc.) }\end{array}$ \\
\hline $31-60$ & $\begin{array}{l}\text { Me's and Women's Hostel, MJP } \\
\text { Rohilkhand University }\end{array}$ & Bareilly & Mass bathing \\
\hline $61-90$ & $\begin{array}{l}\text { Men's and Women's Hostel, MJP } \\
\text { Rohilkhand University }\end{array}$ & Bareilly & $\begin{array}{l}\text { Kitchen discharges including food } \\
\text { wastes }\end{array}$ \\
\hline
\end{tabular}

\subsection{Sampling and examination of periphyton}

Periphytic samples were collected in 10-ml plastic vials using blades, capillary tubes and tooth brushes and within 2 hours, samples were transferred to the laboratory for examination. Five-ml of each sample was used for live diatom examination and the remainder of each sample was fixed with formaldehyde for permanent slide preparation of diatoms. In the collected samples, 45, 30 and 42 different algal species were identified at RWS, KWS and MBS, respectively (Table 2).

Algal cells were identified from online algal resources (Guiry and Guiry, 2021; ANSP Algal Image Database). Algal cells were identified and counted in both fresh and fixed samples, using a Spencer's brightline haemocytometer at 400x magnification under a microscope (Leica, DM 750, Germany). Frustule deformities in the live and permanent slides of diatoms were examined at 1000x magnification (with oil immersion). Four types of deformities in the diatom frustules were identified; namely deformity in: frustule outline (Type 1), striae (Type 2), raphe (Type 3) and mixed or more than one type (Type 4). This categorization is largely based on Pandey et al. (2014).

Several newer diatom metrics (\% motile frustules, life-form, shape of photosynthetic apparatus (chloroplast health status), lipid bodies (LBs), deformities and size reduction) were investigated in the live diatom samples, using a Leica DM 750 microscope attached to a computer for image capturing. Each metric was analyzed using 500 live cells.

Permanent diatom slides were prepared following the protocols given by Pandey et al. (2014). Periphytic diatom samples were treated with acetone for $6 \mathrm{~h}$ and heated at $100{ }^{\circ} \mathrm{C}$ untill the samples were dry. Dried samples were treated with aqua-regia $\left(\mathrm{HCl}\right.$ and $\mathrm{HNO}_{3}$ in ratio of 3:1) for 24 hours, followed by heating on hot plate until dry. Treated dried samples were washed 15 times with distilled water until the $\mathrm{pH}$ of the decanted water was 7 . These water-based, treated samples containing water were dried on cover slips and fixed on glass slides with Pleurax mounting medium (Refractive Index-1.73) using hot plate. The resulting permanent slides of diatoms were mainly used for diatom identification, cell counts and investigation of deformities and size reduction. Fifteen samples $(n=15)$ were taken at each waste site, and 500 diatom frustules were examined for each parameter. 


\subsection{Statistical analysis}

Data (Shannon index, species richness, \% deformities and total deformities) were analysed using oneway analysis of variance (ANOVA) followed by Tukey's HSD test, as appropriate. "PAST" software (Natural History Museum, University of Oslo) was used for data analysis and for calculating the Shannon index for algal samples from different sites.

Table 2. List of algal species found in the Moradabad and Bareilly districts, Uttar Pradesh, India. 


\begin{tabular}{|c|c|c|}
\hline & Species & Abbreviation \\
\hline \multirow[t]{28}{*}{ Bacillariophyceae } & Achnanthes inflata (Kützing) Grunow & AINF \\
\hline & Achnanthidium minutissimum (Kützing) Czarnecki & AMIN \\
\hline & Nitzschia palea & NPAL \\
\hline & Nitzschia linearis & NLIN \\
\hline & Nitzschia amphibia Grunow & NAMP \\
\hline & Nitzschia minuta & NMIN \\
\hline & Navicula gregaria & NGRE \\
\hline & Navicula recens & NREC \\
\hline & Pinnularia viridis (Nitzsch) Ehrenberg & PVIR \\
\hline & Surirella robusta Ehrenberg & SROB \\
\hline & Surirella linearis Smith & SLIN \\
\hline & Surirella brebissonii Krammer et Lange-Bertalot & SBRE \\
\hline & Navicula slesvicensis & NSLE \\
\hline & Gomphonema pala Reichardt & GPAL \\
\hline & Navicula veneta & NVEN \\
\hline & Navicula saprophila & NSAP \\
\hline & Melosira distans & MDIS \\
\hline & Navicula subminusucla & NSUB \\
\hline & Gomphonema parvulum & GPAR \\
\hline & Caloneis bacillum (Grunow) Cleve & CBAC \\
\hline & Achnanthes exigua (Achnanthidium exiguum) & AEXI \\
\hline & Cocconeis placentula & CPLA \\
\hline & Gomphonema turris & GTUR \\
\hline & Pinnularia obscura Krasske & POBS \\
\hline & Sellaphora pupula (Kützing) Meresckowsky & SPUP \\
\hline & Nitzschia fonticola (Grunow) Grunow in Van Heurck & NFON \\
\hline & Nitzschia frustulum (Kutzing) Grunow in Cleve and Grunow & NFRU \\
\hline & $\begin{array}{l}\text { Craticula cuspidate (Kutzing) Mann in Round, Crawford and } \\
\text { Mann }\end{array}$ & CCUS \\
\hline
\end{tabular}




\begin{tabular}{|ll|}
\hline Amphora pediculus (Kutzing) Grunow in A. Schmidt & APED \\
\hline Cymbella tumida (Brebisson ex Kutzing) Van Heurck & CTUM \\
\hline Diploneis elliptica (Kutzing) Cleve & DELL \\
\hline Gomphonema italicum Kutzing & GITA \\
\hline Nitzschia inconspicua Grunow & NINC \\
\hline Rhopalodia gibba (Ehrenberg) Muller & RGIB \\
\hline Pinnularia amabilis Krammer & PAMA \\
\hline Pinnularia graciloides Hustedt in A. Schmidt & PGRA \\
\hline Navicula capitatoradiata Germain & NCAP \\
\hline Cosmarium corda ex Ralfs, 1848 & CCOR \\
\hline Scenedesmus quadricauda (Turpin) Brébisson 1835 & SQUA \\
\hline Oocystis borgei J.W. Snow 1903 & OBOR \\
\hline Chlorella vulgaris & CVUL \\
\hline Closterium kuetzingii & CKUE \\
\hline Spirogyra indica & SIND \\
\hline Selenastrum capricornutum & SCAP \\
\hline Phacus acuminatus (A. Stokes, 1885) & PACU \\
\hline Euglena gracilis (G.A. Klebs, 1883) & EGRA \\
\hline
\end{tabular}

\section{Results}

\subsection{Relative abundance}

Three algal classes were common in the samples; namely Bacillariophyceae; Chlorophyceae and Euglenophyceae (Fig. 3). In addition, blue-green algae (cyanobacteria) were present in all collected samples had low abundance. Species of Bacillariophyceae and Chlorophyceae dominated $(>75 \%)$ at the MBS and KWS sites whereas Euglenophyceae was least abundant (10-20\%). In contrast, dominant classes at RWS were Euglenophyceae and Bacillariophyceae (45\%) an Chlorophyceae was least abundant (20\%).

Dominant algae (species with relative abundance $>1 \%$ ) algal species differed among sites (Fig. 4). At MBS, dominant diatom species were: Nitzschia palea (NPAL) $(15 \%)>N$. amphibia (NAMP) $(15 \%)>N$. 
linearis $(\mathrm{NLIN})(12 \%)>$ Navicula recens $(\mathrm{NREC})(9 \%)>N$. gregaria $(\mathrm{NGRE})(8 \%)>$ Pinnularia virdis $(\mathrm{PVIR})$ $(7 \%)>$ Achnanthidium minutissimum (AMIN) $(5 \%)$, while dominant Chlorophyceae members were Scenedesmus quadricauda (SQUA) (7\%) and Oocystis borgei (OBOR) (7\%). At RWS, dominant euglenoid species were Euglena gracilis (EGRA) (20\%) and Phacus acuminatus (PACU) (18\%), while dominant diatom species were: Nitzschia Palea (NPAL) $(12 \%)>N$. amphibia (NAMP) $(8 \%)>N$. linearis (NLIN) $(8 \%)$ $>$ Navicula recens (NREC) $(5 \%)>N$. gregaria (NGRE) $(5 \%)>$ Achnanthidium minutissimum (AMIN) $(4 \%)$. Only one green alga, i.e., Cosmarium corda (CCOR) (8\%), was abundant at RWS. At KWS, dominant diatom species were Achnanthes inflata (AINF) (20\%) > Nitzschia palea (NPAL) (15\%) > N. amphibia (NAMP) $(12 \%)>N$. linearis (NLIN) $(10 \%)>$ Navicula gregaria (4\%) while dominant Chlorophyceae members were Scenedesmus quadricauda (SQUA) $(5 \%)>$ Oocystis borgei (OBOR) $(5 \%)>$ Cosmarium corda (5\%). Only single euglenoid, i.e., Euglena gracilis (EGRA) (4\%), was abundant at KWS.

\subsection{Shannon index and species richness}

A total of 45 algal species were identified (34 diatom, 9 green algae and 2 euglena species) at the riverine waste sites (Figure 5). Mass bathing sites were most biodiverse with 42 algal species (28 diatom species, 12 green algae and 2 euglena species), whereas Kitchen waste sites were the least diverse with 30 algal species (20 diatom species, 8 green algae and 2 euglena species). Mass bathing samples also had significantly higher Shannon index values $(3.2 \pm 0.3)$ than Kitchen waste sites $(2.1 \pm 0.3)$. Riverine waste sites had intermediate species richness (40 species) and Shannon index values (2.8 \pm 0.3$)$, which were significantly different from KWS but not MBS sites.

\subsection{Life-forms}

Diatoms exhibit several different habitat or growth-form types, collectively referred to here as life-forms. Seven different life-forms were represented in the diatom samples (Rimet et al., 2017) (Table 3). At MBS sites, motile forms dominated ( $40 \%)$, followed by benthic $(20 \%)$ and adnate $(20 \%)$ forms. The remaining four forms (planktonic, colonial, pedunculate and tube-dwelling) were relatively less common, i.e., between $0-5 \%$ for each form. At RWS sites, motile forms were dominant (35\%), followed by benthic (20\%) and colonial (20\%) forms. The remaining four forms (adnate, planktonic, pedunculate and tube-dwelling) were relatively less abundant; i.e., 10, 10, 5 and $0 \%$, respectively. At KWS sites, motile and tube-dwelling forms were dominant; i.e., $45 \%$ and $25 \%$, respectively. The remaining five forms (adnate, planktonic, benthic, colonial and pedunculate) were relatively less abundant; i.e., $10,5,5,5$ and $5 \%$, respectively. 
Table 3

Various life-forms examined at different organically polluted sites.

\begin{tabular}{|llll|}
\hline & $\begin{array}{l}\text { Mass bathing sites } \\
\text { (MBS) }\end{array}$ & $\begin{array}{l}\text { Riverine waste sites } \\
\text { (RWS) }\end{array}$ & $\begin{array}{l}\text { Kitchen waste sites } \\
\text { (KWS) }\end{array}$ \\
\hline Adnate/Pioneer & 20 & 10 & 10 \\
\hline Motile & 40 & 35 & 45 \\
\hline Benthic & 20 & 20 & 5 \\
\hline Planktonic & 5 & 10 & 5 \\
\hline Colonial & 5 & 20 & 5 \\
\hline Pedunculate & 5 & 5 & 5 \\
\hline Tube-dwelling & 5 & 0 & 25 \\
\hline
\end{tabular}

\subsection{Alteration in photosynthetic apparatus (Chloroplast health status)}

The health status of live diatoms were classified as healthy (live cells with intact protoplasmic content), unhealthy (distorted protoplasmic content) and dead (nearly vacant cells) as per Pandey et al. 2017 (Figs. 6 and 7). At MBS sites, percentages of healthy and unhealthy cells were equal (40\%) while the percentage of dead cells was low (20\%) - this site had the highest percent of unhealthy cells. At RWS sites, healthy, unhealthy and dead cells percentages were 50, 35 and $15 \%$, respectively. At KWS sites, healthy, unhealthy and dead cells percentage 60,20 and 10\%, respectively - giving the site the lowest percent of unhealthy cells.

\subsection{Lipid bodies (LBs)}

Lipid bodies were examined (in terms of number and percent biovolume contribution) in the dominant diatom species at the sites (Fig. 8; Table 4a, b and c). At MBS sites, LB bearing diatom genera were Nitzschia (N. amphibia and N. linearis, with 0-6 LBs per cell) and Navicula (N. slesvicensis, N. gregaria and $N$. veneta, with 0 to 2 LBs per cell). Nitzschia amphibia and Navicula gregaria high percent biovolume contributions of LBs; i.e., 5-10\% and 8-20\%, respectively, while other diatom species had relatively lower LB biovolume contributions. At RWS sites, LBs bearing diatom taxa were Nitzschia species ( $N$. amphibia, N. palea and N. linearis, 0-6 LBs per cell), Navicula gregaria (0-4 LBs per cell) and Calonies bacillus (0-2 LBs per cell). Percent biovolume contribution of LBs, was elevated in only Nitzschia amphibia (6-10\%), while LB percent contributions in the other measured species were relatively low. At KWS sites, LBs bearing diatom genera were Nitzschia ( $N$. amphibia, N. palea and $N$. linearis, with 0-6 LBs per cell) and Navicula (N. gregaria and $N$. veneta, with 0-2 LBs per cell). At this site, only Nitzschia species $(N$. amphibia and $N$. linearis) had a relatively higher percent biovolume contribution of LBs (8-12\% and 6$10 \%$, respectively). 
Table 4

a. Lipid body status in dominant diatom species from mass bathing sites (MBS).

\begin{tabular}{|lll|}
\hline & $\begin{array}{l}\text { No. of Lipid bodies } \\
\text { (LBs) }\end{array}$ & $\begin{array}{l}\text { Percent biovolume contribution of lipid bodies } \\
\left(\mu^{3}\right)^{3}\end{array}$ \\
\hline N. amphibia & $0-4$ & $5-10$ \\
\hline N. linearis & $0-6$ & $5-8$ \\
\hline $\begin{array}{l}\text { Navicula } \\
\text { slesvicensis }\end{array}$ & $0-2$ & $2-6$ \\
\hline N. gregaria & $0-2$ & $8-20$ \\
\hline N. veneta & $0-2$ & $2-5$ \\
\hline
\end{tabular}

Table 4

b. Lipid body status in dominant diatom species from riverine waste sites (RWS).

\begin{tabular}{|c|c|c|}
\hline & No. of Lipid bodies (LBs) & Percent biovolume contribution of lipid bodies $\left(\mu \mathrm{m}^{3}\right)$ \\
\hline Nitzschia palea & $0-6$ & $4-6$ \\
\hline N. amphibia & $0-6$ & $6-10$ \\
\hline N. linearis & $0-4$ & $4-6$ \\
\hline N. gregaria & $0-4$ & $2-6$ \\
\hline Caloneis bacillus & $0-2$ & $2-4$ \\
\hline
\end{tabular}

Table 4

c. Lipid body status in dominant diatom species from kitchen waste sites (KWS).

\begin{tabular}{|lll|}
\hline & No. of Lipid bodies (LBs) & Percent biovolume contribution of lipid bodies $\left(\mu \mathrm{m}^{3}\right)$ \\
\hline Nitzschia palea & $0-4$ & $4-6$ \\
\hline N. amphibia & $0-4$ & $8-12$ \\
\hline N. linearis & $0-6$ & $6-10$ \\
\hline Navicula veneta & $0-2$ & $2-4$ \\
\hline N. gregaria & $0-2$ & $2-5$ \\
\hline
\end{tabular}

\subsection{Deformities}

Deformities in diatom cells were examined through permanent slide preparation (Figs. 9 and 10, Table 5). Deformed frustules were mainly present in Navicula saprophila, N. subminuscula, Nitzschia palea, Navicula slesvicensis, Melosira distans, Gomphonema parvulum and Nitzschia minuta. Deformed diatom frustules were significantly more prevalent at RWS $(0.4 \pm 0.05 \%)$ in comparison to the relatively lower percentages of deformed frustules at MBS and KWS (i.e., $0.2 \pm 0.10 \%$ and $0.2 \pm 0.05 \%$, respectively). Morphological deformities in diatom frustules were divided into four types as per Pandey et al. (2014). 
Type 1 (frustule outline) deformities were found at all three waste sites but Type 2 (striae) deformities were found only at RWS. Type 3 (raphe) and Type 4 (mixed) deformities were not found at any of the three waste sites.

\section{Table 5}

Total percent of deformities among selected diatom taxa and the relative proportion of deformity types in diatom frustules at the sampled waste sites in Moradabad and Bareilly. Different superscript letters indicate significant different differences in the percent of deformities among sites $(P<0.05$ : Tukey's HSD test).

\begin{tabular}{|llll|}
\hline & $\begin{array}{l}\text { Mass Bathing Sites } \\
\text { (MBS) }\end{array}$ & $\begin{array}{l}\text { Riverine Waste Sites } \\
\text { (RWS) }\end{array}$ & $\begin{array}{l}\text { Kitchen Waste Sites } \\
\text { (KWS) }\end{array}$ \\
\hline $\begin{array}{l}\text { Total Deformity } \\
(\%)\end{array}$ & $0.2 \pm 0.10^{\mathrm{a}}$ & $0.4 \pm 0.05^{\mathrm{b}}$ & $0.2 \pm 0.05^{\mathrm{a}}$ \\
\hline Type 1 & 100 & 50 & 100 \\
\hline Type 2 & 0 & 50 & 0 \\
\hline Type 3 & 0 & 0 & 0 \\
\hline Type 4 & 0 & 0 & 0 \\
\hline
\end{tabular}

\section{Discussion}

In the present study, three specific, nutrient-enriched waste sites were characterized using a variety of traditional (taxonomic) and newer diatom (non-taxonomic) metrics to assess the potential of these metrics for biomonitoring. Three classes of algae dominated the investigated waste sites:

Bacillariophyceae; Chlorophyceae and Euglenophyceae. Of these three classes, Bacillariophyceae were the most abundant at all three waste sites. This finding was not in agreement with the findings of Palmer (1969), who reviewed more than 200 research papers dealing with organic contamination and algal diversity. Palmer (1969) reported numerical dominance of Chlorophyceae, followed by Bacillariophyceae under conditions of organic pollution. The difference in dominant algal class with organic pollution is likely due to the type of algal community sampled in our study, in which we sampled periphytic algal communities. These substrate-associated communities are considered permanent residents of the waterbodies due to their attach nature. In contrast, many green algae are phytoplanktonic and most attached forms are filamentous. In contrast, periphytic diatoms have the excellent adhesive properties and can attach to almost any available substrate and thereby dislodgement due to normal currents found in the fluvial waterbodies. In terms of genera, Palmer (1969) reported the dominance of Euglena (Euglenophyceae), and Chlamydomonas, Scenedesums and Chlorella (Chlorophyceae) at organically polluted sites. In contrast, we found that the diatom genera Nitzschia and Navicula dominated at all three waste sites., whereas Palmer (1969) ranked these genera in the 6th and 7th places, respectively. At the species level, the riverine waste sites (RWS) had high abundance of Euglena gracilis and Nitzschia palea, species that Palmer (1969) considered characteristic of contaminated sites. Findings at MBS and KWS sites similarly had high abundance of Nitzschia palea but Euglena gracilis was low in comparison to 
diatom species. In our view, we think that findings of Palmer (1969) need further examination, especially incorporating information about the type of algal community (phytoplanktonic, periphytic and benthic) sampled and how these habitat-based communities might produce different results. Better understanding of habitat differences will contribute toward developing more effective biomonitoring strategies for organic pollution.

Biodiversity metrics are regularly used for biomonitoring purposes (Pandey et al., 2017). Species richness and Shannon index values of the sampled algal communities had significantly lower values at KWS versus the significantly higher values found at MBS and RWS. Lower index values at KWS may be due to particular contaminants associated with kitchens, such as insecticide and pesticide contaminants (from washing of vegetables and fruits) or soaps and detergents that accompany the nutrient enrichment. Shannon index value $>3$ is considered as clean water quality while values between 1-3 are considered as moderately polluted and value $<1$ is considered polluted (Gökçe, 2016). On this basis, MBS sites (3.2) are relatively clean while RWS (2.8) and KWS (2.1) sites are moderately polluted. However, field observation of these sites is at odds with these results. RWS, MBS and KWS have long history of organic contamination, as they are continuously polluted by their respective discharges (soaps, detergents, toothpastes, shampoo discharges, cooking oils, waste foods, discharges from ritual practices etc.) since from their formation as drainages. Soininen et al. (2012) also reported species richness as a single metric may provide incomplete information about aquatic ecosystems. In the same context, Blanco, (2012) examined 640 sites of France and found poor linear correlations among environmental factors indicating ecological status and came to the conclusion that biodiversity indices provide inconsistent information about the known impairment of the waterbodies. Biodiversity indices-based analysis is strongly dependent upon cell counts and the correct taxonomic identification of algae. The indices are susceptible to change with any environmental and anthropogenic disturbance.

Diatom life-forms (benthic, planktonic, motile, colonial, tube-dwelling, stalked and adnate) can have application in biomonitoring. Different life-forms of diatoms provide different strategies to resist or tolerate some environmental and anthropogenic stresses. In the present study, all sites were dominated by motile forms. Motile forms may be associated with: (1) the secretion extracellular enzymes that allow motile diatoms to more easily use macromolecules adsorbed on substrates (Pringle, 1990). (2) the larger size of motile diatoms relative to adnate diatoms make them better equipped to store more nutrients. (3) motile diatom forms can easily move from nutrient deficient microenvironments to nutrient enriched locations (Johnson et al., 1997). KWS sites also had a high abundance of tube-dwelling diatom forms, which were only common at this site. Tube dwelling diatoms have been reported in nutrient and organicmatter contaminated sites (Marcel et al., 2013). Fricke et al. (2017) reported higher dominance of tubedwelling diatom (Berkeleya rutilans) as an indicator of eutrophication in sedimentary marine habitats of Argentinean waters. Tube dwelling diatom forms have also been reported under herbicide and fungicide exposure in a lotic mesocosm experiment (Rimet and Bouchez, 2011). In the present study, kitchen waste sites can be contaminated with pesticides and herbicides, which comes from the washing fruits and vegetables. RWS sites are more uniform in distribution of different life-forms than KWS and MBS sites. Understanding the role of various life-forms within biofilms enables better understanding of species- 
environment relationships and interactions, which is critical for developing effective biomonitoring strategies for aquatic ecosystem (Rimet and Bouchez, 2011; Pandey et al., 2017).

Observations of live samples of periphytic diatoms provide valuable information about the ecological status of the collection sites (Pandey et al., 2017). Fresh samples include healthy (live), unhealthy and dead diatom frustules in different proportions. Diatom cells with intact, distorted and empty protoplasmic content are considered as healthy, unhealthy and dead diatoms, respectively (Agusti et al., 2015; Pandey et al., 2018). In the past several years, several authors have used diatom health as an indicator of ecological health of waterbodies (Pandey et al., 2017, 2018; Werdel et al., 2021). In the present study, KWS and RWS sites showed higher dominance (> 50\%) of live (healthy) frustules than unhealthy and dead frustules, possibly because of the availability of nutrients for the diatom cells at these sites. Similarly, a higher proportion of healthy diatom cells was also examined in eutrophic lakes of Florida, USA. High nutrients may support diatom cell reproduce at a faster rate, which produces new and rejuvenated cells regularly. These sites also bear contamination of pesticides, herbicides and metals (at RWS), which can result in unhealthy cells even in the presence of nutrient enrichment. Wood et al. (2014, 2016) reported visible changes in diatom chloroplasts under exposure to different types of herbicides (atrazine, simazine, hexazinone, tebuthiuron, diuron, MCPA, 2,4-D and glyphosphate). Debenest et al. (2008) also reported alteration in chloroplast morphology under herbicide exposure. Alteration in chloroplast morphology can also result from metal stress (Licursi and Gómez, 2013: Pandey and Bergey, 2016). At MBS sites, healthy diatom cells had lower abundance than unhealthy diatom cells. This may be due to intermittent availability of nutrients, as nutrients are regularly flushed out, often creating nutrient deficient conditions. Nutrient depletion was also associated with deteriorated cell status in bloom forming diatoms, which is associated with large sinking events in the Arctic (Svalbard Islands) region (Agusti et al., 2018).

Different algal groups are classified partly on the basis of the type of reserve food materials. In diatoms, the chief reserve food is in the form of lipid bodies (LBs). Under stress, LBs in diatoms may show increase in number and percent biovolume contribution per cell. In the present study, LBs number and its biovolume contribution per cell showed appreciable changes, especially in Nitzschia and Navicula species. Higher abundance of Nitzschia species is regularly reported under organic contamination but the information regarding LBs is still lacking. However, the present study showed that contamination of nutrients and organic matter may also affect LBs. Among the investigated diatom species, Nitzschia palea and Achnanthes exigua had normal lipid body numbers but their biovolume contribution per cell was appreciably elevated, i.e., up to $16 \%$ and $30 \%$, respectively. Induction of LBs in various diatom species is well documented under metal stress. Higher abundance of LBs in Achnanthidium exiguum (Achnanthes exigua) was reported under metal stress, as was increased LB percent biovolume. i.e., 20$77 \%$ and $13-53 \%$ under $\mathrm{Cu}$ and $\mathrm{Zn}$ stress, respectively. Pandey et al. (2018) reported higher abundance of LBs in Nitzschia palea under metal (Cu, Zn and Ni) stress, i.e., 8-25\%. Similarly, Pandey and Bergey (2018) reported $50-60 \%$ LBs contribution per cell under Cu and Zn stress in the River Ganga, India. Extra LBs (in number and biovolume) may help diatoms combat stress and provide an additional food source. LBs in diatoms also affect buoyancy (Smetacek, 2001) under stress conditions and may enable them to 
maintain a proper depth in the water column, as sinking is associated with cell death (Agusti et al., 2018). Also, by helping regulate buoyancy, LBs inside diatom cells assist in cell movement (Wang et al., 2013), which may help diatoms move from nutrient deficient microenvironments to nutrient enriched conditions. Excess nutrients in the aquatic environment can support bloom formation of diatom cells, and as a result, a rapid decrease in nutrient concentration in the water column takes place, which may result in the poor health of live diatoms (shrinkage of protoplasmic content) and an associated enhancement of LBs in response to nutrient stress. LB induction in diatom samples from all three riverine waste sites clearly indicate stress, presumably associated with the high (and possibly changing) nutrient loads.

Diatoms are well known for their silicon cell wall, which is faithfully reproduced through the generations. Silicon frustules also bears species-specific ornamentation (especially striae and the raphe), which are extremely useful in the identification of diatom species. Any change in the normal morphology (outline, striations and raphe) of diatom frustules considered deformed. In the present study, deformed frustules were found in Navicula saprophila, N. subminuscula, N. slesvicensis, Nitzschia palea, N. minuta, Gomphonema parvulum and Melosira distans. Deformities in diatom frustules are only occasionally reported under nutrient and organic stress. Dziengo-Czaja et al. (2008) similarly reported deformities in diatoms under organic matter load (nitrate and phosphate) in the Western Puck Bay of the Baltic Sea, but the reported species differed from those we found because Dziengo-Czaja et al. (2008) worked in a marine rather than our freshwater environment and the two environments have little species overlap (Pandey et al., 2018). In comparison to fresh water, marine waters showed relatively bigger size of diatom species (Litchman et al., 2009) due to which the chances of getting deformed frustules under such conditions get increased.

Riverine waste sites (RWS) had significantly more deformities in diatom frustules at than MBS and KWS, although the overall rate of deformities was not high (less than $0.5 \%$ ). The main reason for this higher percentage of deformed diatom frustules at RWS is that riverine waste sites bear the legacy of cocktail of pollutants (nutrients, organic matters, metals etc.) coming from household discharges, agricultural runoff, discharges from waste treatment plants and metals discharge from brass factories. Thus, the cumulative effect of these toxicants results in a higher percent deformed frustules at riverine waste sites. Generally, high rates of deformed frustules are reported under metal stress. For example, in a laboratory mesocosm experiment, $\mathrm{Cu}$ and $\mathrm{Zn}$ exposure produced $6 \%$ and $8 \%$ deformed diatom frustules (Pandey et al., 2015). Field conditions had comparable deformity rates, with $8.16 \%(\mathrm{Zn})$ and $14 \%(\mathrm{Cu})$ deformed diatom frustules from severely metal polluted metalliferous sites of Zawar and Khetri (Pandey et al., 2016) and 6$8 \%$ deformed frustules under metal contamination ( $\mathrm{Cu}, \mathrm{Zn}$ and $\mathrm{Ni}$ ) at the Soyo site in the Han River, South Korea. In the present study, deformities were more common in raphid diatoms than araphid diatoms, although araphid diatoms generally show higher percentages of deformities than raphid diatoms (Pandey et al., 2017). Frustules of raphid diatoms bear an especially long continuous opening (raphe), which may provide a gateway for particular toxicants to enter the cells and cause deformities. In the present study, Type 1 (frustule outline) deformities are prevalent at all three examined waste sites and Type 2 (striae) deformities were found only at riverine waste sites (RWS), but individual diatoms with both types of deformities were not observed. Past studies indicate that the occurrence of more than one type 
of deformity in diatom samples is a strong indicator of metal contamination (Pandey et al., 2015; Pandey et al., 2016; Pandey et al., 2017), which adds evidence of metal contamination at RWS, although the $0.4 \%$ occurrence of deformities at this site is below the $>1 \%$ that is considered a significant indicator of metal contamination (Morin et al., 2016; Pandey et al., 2017).

Our results indicated that the three investigated sites are all affected by organic matter enrichment, but may also be affected by other contaminants (e.g., nutrients and metals). Presence of elevated nutrients results higher cell growth (cell division), which may enhance uptake of other contaminants (metals, pesticides, insecticides), which is manifested in the dominance of nitzschoid diatoms, higher unhealthy cells, induction of lipid bodies (higher number, size and biovolume) and the presence of deformed cells.

\section{Conclusions}

Traditional biodiversity methods indicated some impairment, with the three sites ordered from best to worst as: MBS > RWS > KWS, based on species richness and the Shannon index. The non-traditional diatom metrics presented a more complex picture of the three sites - enlarged lipid bodies in some diatoms and dominance by motile diatoms at all sites indicated stress and nutrient/organic matter contamination, respectively - but other metrics differentiated the sites. RWS had a higher rate and two different types of deformities in diatom frustules, indicating possible metal contamination. The high rate of tube-dwelling diatoms at KWS may result from high nutrient loads or specific contaminants (e.g., herbicides or fungicides). MBS (the 'best' site as indicated with traditional metrics) also had the highest proportion of unhealthy diatoms (based on chloroplast and cytoplasm condition), which may indicate slower diatom turnover because of relatively lower nutrient concentrations or fluctuating nutrient availability compared to the other two sites.

Incorporating newer, non-traditional diatom metrics provided additional evidence about the types of stresses experienced by the biota at each site. Because these diatom metrics are also relatively faster, less expensive, and require less expertise, developing biomonitoring strategies that incorporate both traditional and non-traditional metrics is cost effective and will increase understanding of both the ecological heath and possible reasons for impairment.

\section{Declarations}

\section{Declaration of conflict of interest}

The authors declare that they have no known competing financial interests or personal relationships that could have appeared to influence the work reported in in this paper.

\section{CRediT authorship contribution statement}

Lalit K. Pandey: Conceptualization, Methodology, Validation, Formal analysis, Investigation, Data curation, Writing - original draft, Writing - review \& editing, Visualization. 
Aafiya Shameem: Validation, Formal analysis, Investigation, Data curation, Writing - original draft, Writing - review \& editing, Visualization.

Harshita Gupta: Investigation, Data curation, Writing - original draft, Writing - review \& editing, Visualization.

Sangeeta: Validation, Formal analysis, Investigation, Data curation, Writing - original draft, Writing review \& editing, Visualization.

Sanjeev Kumar Maurya: Investigation, Data curation, Writing - original draft, Writing - review \& editing, Visualization.

Virendra Kumar: Investigation, Data curation, Writing - original draft, Writing - review \& editing, Visualization.

Elizabeth A. Bergey: Formal analysis, Investigation, Data curation, Writing - original draft, Writing - review \& editing, Visualization.

Jyoti Chaubey: Investigation, Data curation, Writing - original draft, Writing - review \& editing, Visualization.

Sudeeksha Negi: Investigation, Data curation, Writing - original draft, Writing - review \& editing, Visualization.

Divyanshi Gupta: Investigation, Data curation, Writing - original draft, Writing - review \& editing, Visualization.

Mahima Gupta: Investigation, Data curation, Writing - original draft, Writing - review \& editing, Visualization.

Abhisekh Kumar: Investigation, Data curation, Writing - original draft, Writing - review \& editing, Visualization.

Shivangi Singh: Investigation, Data curation, Writing - original draft, Writing - review \& editing, Visualization.

\section{Data availability}

-All data provided in the ms.

\section{Animal Research (Ethics)}

-No animal used in this research work.

\section{Consent to Participate (Ethics)}


- Ready to participate.

\section{Consent to Publish (Ethics)}

- Ready to publish in subscription.

\section{Plant Reproducibility}

- No plant used. We do research on algae.

\section{Clinical Trials Registration}

- No clinical registration requires as work is on algae.

\section{Data availability statement}

All data generated or analysed during this study are included in this published article.

\section{Acknowledgements}

This work was supported by SERB-SRG (File No. SRG/2020/000432). Sangeeta is thankful to SERB (for JRF) and Head Dept of Plant Science, MJP Rohilkhand University, Bareilly for providing laboratory facilities.

\section{References}

1. Agusti, S., Alou, E., Hoyer, M.V., Frazer, T.K., Canfield, D.E. 2006. Cell death in lake phytoplankton communities. Freshwater Biology. 51: 1496-1506.

2. Agusti, S., Gonzalez- Gordillo, J.I., Vaque, D., Estrada, M., Cerezo, M.I., Salazar, G., Gasol, J.M., Duarte, C.M. 2015. Ubiquitous healthy diatoms in the deep sea confirm deep carbon injection by the biological pump. Nature Communication. 6; 7608.

3. Agusti, S., Krause, J.W., Marquez, I.A., Wassmann, P., Kristiansen, S., Duarte, C.M. 2020. Arctic (Svalbard islands) active and exported diatom stocks and cell health status. Biogeosciences. 17: 3545.

4. ANSP Algae Image Database from the Phycology Section, Patrick Center for Environmental Research, The Academy of Natural Sciences at http://diatom.acnatsci.org/Algaelmage/

5. Bettinetti, R., Ponti, B., Marziali, L., Rossaro, B., 2012. Biomonitoring of lake sediments using benthic macroinvertebrates. Trend. Anal. Chem. 36, 91-102.

6. Blanco, S., Cejudo-Figueiras, C., Tudesque, L., Becares, E., Hoffmann, L., Ector, L., 2012. Are diatom diversity indices reliable monitoring metrics? Hydrobiologia 695, 199-206.

7. Debenest, T., Silvestrea, J., Coste, M., Delmas, F., Pinelli, E., 2008. Herbicide effects on freshwater benthic diatoms: induction of nucleus alterations and silica cell wall abnormalities. Aquat. Toxicol. 
88, 88-94.

8. Dwivedi, S., Chauhan, P.S., Mishra, S., Kumar, A., Singh, P.K., Kamthan, M., Chauhan, R., Awasthi, S., Yadav, S., Mishra, A., Mallick, S., Ojha, S.K., Tewari, S.K., Tripathi, R.D., Nautiyal, C.S. 2020. Selfcleansing properties of Ganga during mass ritualistic bathing on Maha-Kumbh. Environmental Monitoring and Assessment. 192:221.

9. Dwivedi, S., Mishra, S., Tripathi, R.D., 2018. Ganga water pollution: A potential health threat to inhabitants of Ganga basin. Environ. Int. 117, 327-338.

10. Dziengo-Czaja, M., Koss, J., Matuszak, A., 2008. Teratological forms of diatoms as indicators of water pollution in the western part of Puck Bay southern Baltic Sea. Oceanol. Hydrobiol. St. 37, 119132.

11. Falasco, E., F. Bona, G. Badino, L. Hoffmann and L. Ector. 2009. Diatom teratological forms and environmental alterations: A review. Hydrobiologia623:1-35.

12. Falasco, E., Ector, L., Wetzel, C.E., Badino, G., Bona, F. 2021. Looking back, looking forward: a review of the new literature on diatom teratological forms (2010-2020). Hydrobiologia. 848: 1675-1753.

13. Fricke, A., Kihara, T.C., Kopprio, G.A., Hoppenrath, M. 2017. Anthropogenically driven habitat formation by a tube dwelling diatom on the Northern Patagonian Atlantic coast. Ecological Indicators. 77: 8-13.

14. Gillett, N., Y. Pan and C. Parker. 2009. Should only live diatoms be used in the bioassessment of small mountain streams? Hydrobiologia 620:135-147.

15. Gillett, N.D., Y. Pan, K.M. Manoylov and R.J Stevenson. 2011. The role of live diatoms in bioassessment: A large-scale study of Western US Streams. Hydrobiologia665:79-92.

16. Gökçe, D (2016). Algae as an Indicator of Water Quality, Algae - Organisms for Imminent Biotechnology, Nooruddin Thajuddin and Dharumadurai Dhanasekaran, IntechOpen.

17. Guiry, M.D. \& Guiry, G.M. 2021. AlgaeBase. World-wide electronic publication, National University of Ireland, Galway. https://www.algaebase.org; searched on 05 August 2021.

18. Johnson, R.E., Tuchman, N.C., Peterson, C.G., 1997. Changes in the vertical microdistribution of diatoms within a developing periphyton mat. J. N. Am. Benthol. Blanco Soc. 16, 503-519.

19. Krause, J.W., Schulz, I. K., Rowe, K. A., Dobbins, A., Winding, M. H. S., Sejr, M. K., Duarte C. M., Agusti S., 2019. Silicic acid limitation drives bloom termination and potential carbon sequestration in an Arctic bloom. Scientific Reports (2019) 9:8149

20. Licursi, M., Gomez, N., 2013. Short-term toxicity of hexavalent-chromium to epi-psammic diatoms of a microtidal estuary (Río de la Plata): responses from the individual cell to the community structure. Aquat. Toxicol. 134-135, 82-91.

21. Litchman, E., Klausmeier, C.A., Yoshiyama, K., 2009. Contrasting size evolution in marine and freshwater diatoms. Proc. Natl. Acad. Sci. 106, 2665-2670.

22. Marcel, R., Bouchez, A and Rimet, F. 2013. Influence of herbicide contamination on diversity and ecological guilds of river diatoms. Cryptogamie Algologie. 34 (2); 169-183. 
23. McCormick, P.V., Cairns Jr., J., 1994. Algae as indicators of environmental change. J. Appl. Phycol. 6, $509-526$.

24. Morin, S., Cordonier, A., Lavoie, I., Arini, A., Blanco, S., Duong, T.T., Tornes, E., Bonet, B., Corcoll, N., Faggiano, L., Laviale, M., Per es, F., Becares, E., Coste, M., Feurtet-Mazel, A., Fortin, C., Guasch, H., Sabater, S., 2012. Consistency in diatom response to metal-contaminated environments. In: Guasch, H., Ginebreda, A., Geiszinger, A. (Eds.), Emerging and Priority Pollutants in Rivers. SpringerVerlag, Berlin, pp. 117-146.

25. Morin, S., Gomez, N., Tornes, E., Licursi, M., Rosebery, J., 2016. Benthic diatom monitoring and assessment of freshwater environments: standard methods and future challenges. In: Romaní, A.M., Guasch, H., Balaguer, M.D. (Eds.), Aquatic Biofilms: Ecology, Water Quality and Water Treatment. Caister Academic Press, U.K, pp. 111e124.

26. Palmer, C.M., 1969. A composite rating of algae tolerating organic pollution. J. Phycol. 5, 78-82.

27. Pandey, L.K., Kumar, D., Yadav, A., Rai, J., Gaur, J.P., 2014. Morphological abnormalities in periphytic diatoms as a tool for biomonitoring of heavy metal pollution in a river. Ecol. Indic. 36, 272-279.

28. Pandey, L.K., Han, T., Gaur, J.P., 2015. Response of a phytoplanktonic assemblage to copper and zinc enrichment in microcosm. Ecotoxicology. 24: 573-582.

29. Pandey, L.K., Bergey, E.A., 2016. Exploring the status of motility, lipid bodies, deformities and size reduction in periphytic diatom community from chronically metal $(\mathrm{Cu}, \mathrm{Zn})$ polluted waterbodies as a biomonitoring tool. Sci. Total Environ. 550, 372-381.

30. Pandey, L.K., Bergey, E.A., Lyu, J., Park, J., Choi, S., Lee, H., Depuydt, S., Oh, Y.-T., Lee, S.-M., Han, T., 2017. The use of diatoms in ecotoxicology and bioassessment: insights, advances and challenges. Water Res. 118, 39-58.

31. Pandey, L.K., Bergey, E.A., 2018. Metal toxicity and recovery response of riverine periphytic algae. Sci. Total Environ. 642, 1020-1031.

32. Pandey, L.K., Lavoie, I., Morin, S., Park, J., Lyu, J., Choi, S., Lee, H., Han, T., 2018a. Riverwater quality assessment based on a multi-descriptor approach including chemistry, diatom assemblage structure, and non-taxonomical diatom metrics. Ecol. Indic. 84, 140-151.

33. Pandey, L.K., Sharma, Y.C., Park, J., Choi, S., Lee, H., Jie, L., Han, H., 2018b. Evaluating features of periphytic diatom communities as biomonitoring tools in fresh, brackish and marine waters. Aquat. Toxicol. 194, 67-77.

34. Park, J., Lee, H., Depuydt, S., Han, T., Pandey, L.K., 2020. Assessment of five live-cell characteristics in periphytic diatoms as a measure of copper stress. J. Hazard. Mater. 400, 1-9, 123113.

35. Pringle, C.M., 1990. Nutrient spatial heterogeneity: effects on community structure, physiognomy, and diversity of stream algae. Ecology 71, 905-920.

36. Paul, D (2017). Research on heavy metal pollution of river Ganga: A review. Annals of Agrarian Science. 15 (2): 278-286.

37. Rai, U.N., Tripathi, R.D., Singh, N.K., Upadhyay, A.K., Dwivedi, S., Shukla, M.K., Mallick, S., Singh, S.N., Nautiyal, C.S. 2013. Constructed wetland as an ecotechnological tool for pollution treatment for 
conservation of Ganga river. Bioresour. Technol. 148, 535-541.

38. Rimet, F., Bouchez, A., 2011. Use of diatom life-forms and ecological guilds to assess pesticide contamination in rivers: lotic mesocosm approaches. Ecol. Indic. 11, 489-499.

39. Smetacek, V., 2001. A watery arms race. Nature 411 (745).

40. Soininen, J., Passy, S., Hillebrand, H., 2012. The relationship between species richness and evenness: a meta-analysis of studies across aquatic ecosystems. Oecologia. 169: 803-809.

41. Stevenson, R.J., Pan, Y., Vandam, H., 2010. Assessing environmental conditions in rivers and streams with diatoms. In: Smol, J.P., Stoermer, E.F. (Eds.), The Diatoms: Applications for the Environmental and Earth Sciences, 2nd edition. Cambridge University Press.

42. Wang, J., S. Cao, C. Du and D. Chen. 2013. Underwater locomotion strategy by a benthic pennate diatom Navicula sp. Protoplasma250:1203-1212.

43. Wood, R.J., S.M. Mitrovic and B.J. Kefford. 2014. Determining the relative sensitivity of benthic diatoms to atrazine using rapid toxicity testing: A novel method. Sci. Total Environ.485-486:421427.

44. Wood, R.J., S.M. Mitrovic, R.P. Lim and B.J. Kefford. 2016. How benthic diatoms within natural communities respond to eight common herbicides with different modes of action. Sci. Total Environ. 557-558:636-643.

45. Wolska, L.W., Sagajdakow, A., Kuczyńska, A., Namieśnik, J., 2007. Application of ecotoxicological studies in integrated environmental monitoring: possibilities and problems. Trends Anal. Chem. 26, 332-344.

46. Werdel, G.M., Pandey, L.K., Bergey, E.A. 2021. Cigarette butt effects on diatom health in a stream ecosystem. Aquatic Ecology. 55: 999-1010.

\section{Figures}



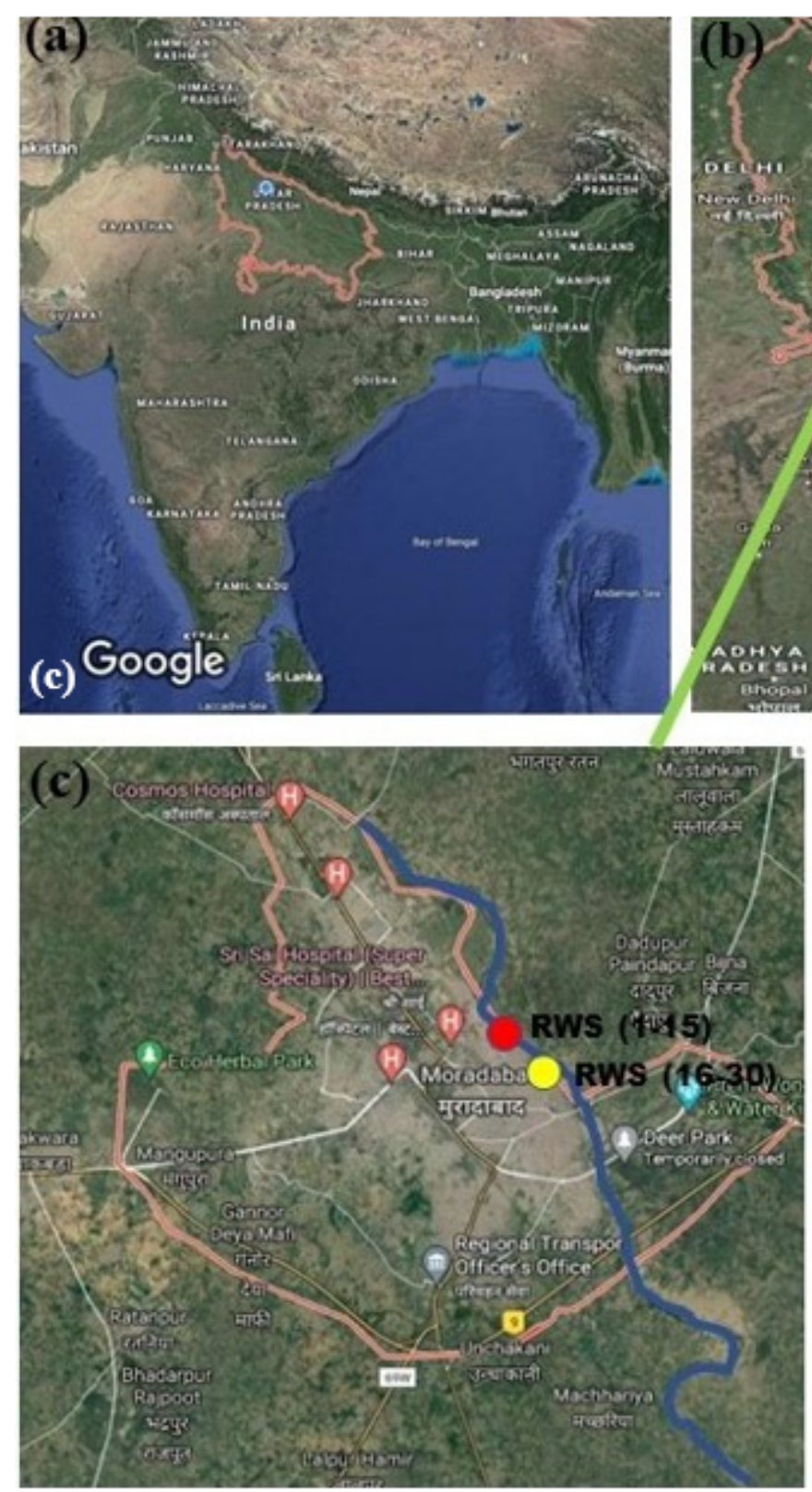
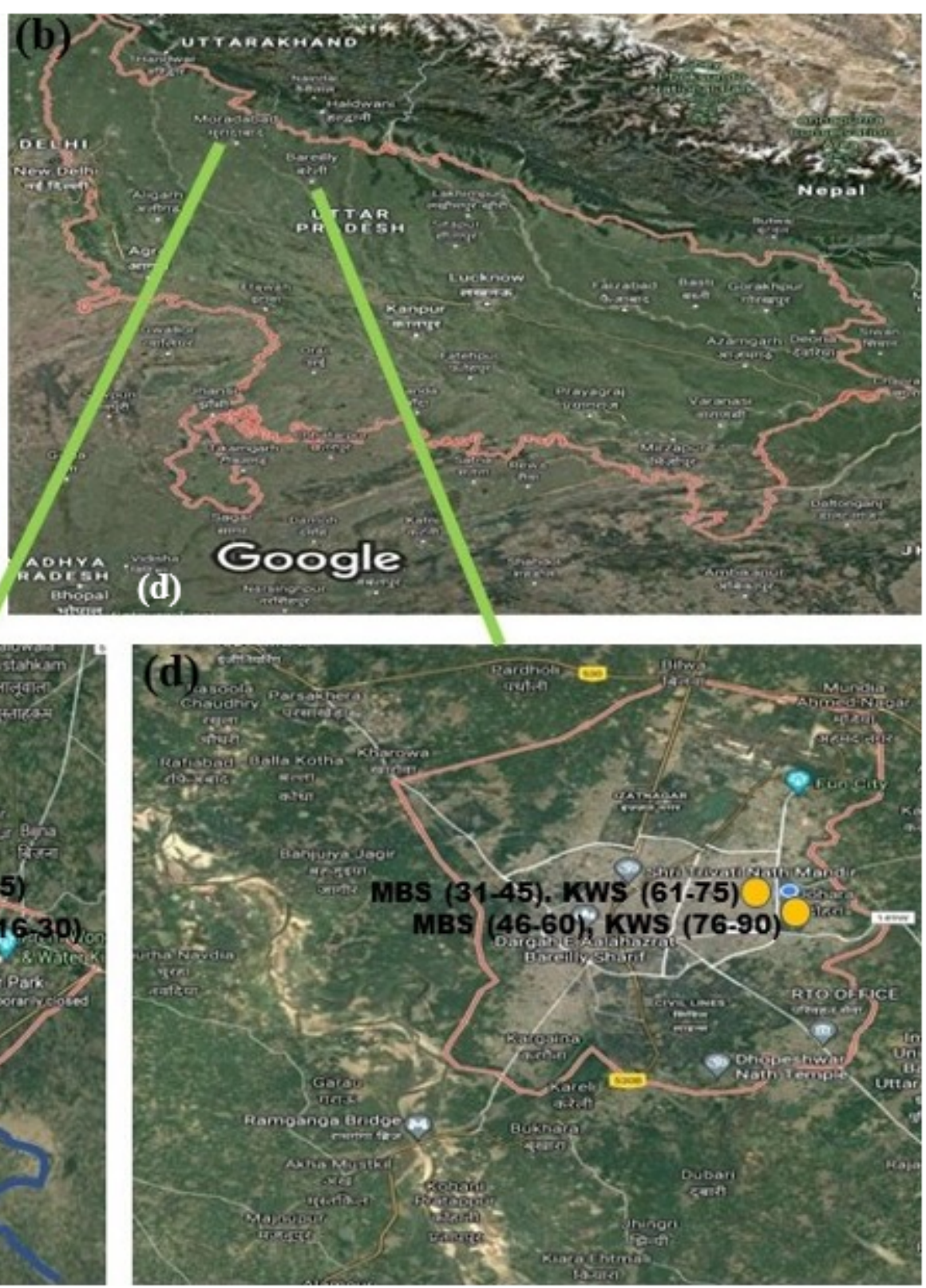

\section{Figure 1}

Photographic maps of the waste sites surveyed for the collection of periphytic algal communities and water samples. (a) Picture showing location of Uttar Pradesh in India, (b) Uttar Pradesh showing Moradabad and Bareilly districts, (c) Enlarged view of Moradabad district showing various sites surveyed and the type of waste sites (RWS-Riverine waste site) $w$ the sample numbers and hence the number of samples indicated. The blue line shows the local stretch of Ram Ganga River and (d) Enlarged view of Bareilly district showing the sites surveyed and the type of waste (MBS-Mass bathing sites and KWSKitchen waste sites) sites with numbers showing samples numbers. 
Riverine waste sites (RWS)
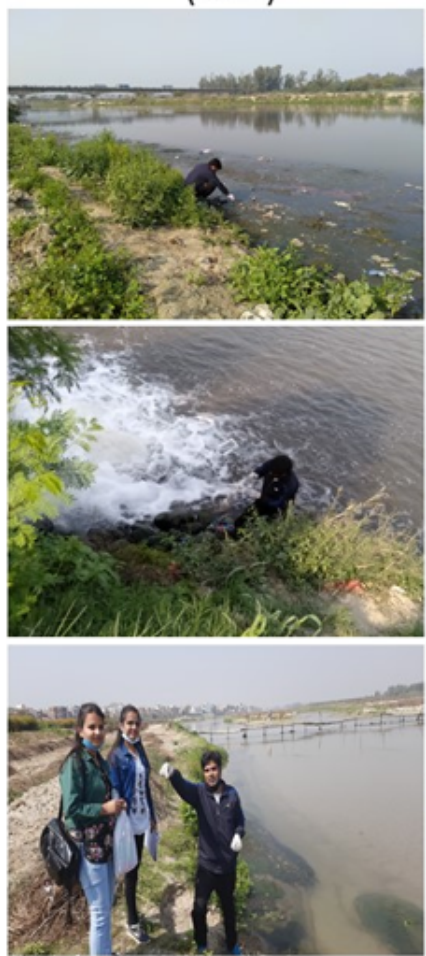

Kitchen waste sites

(KWS)
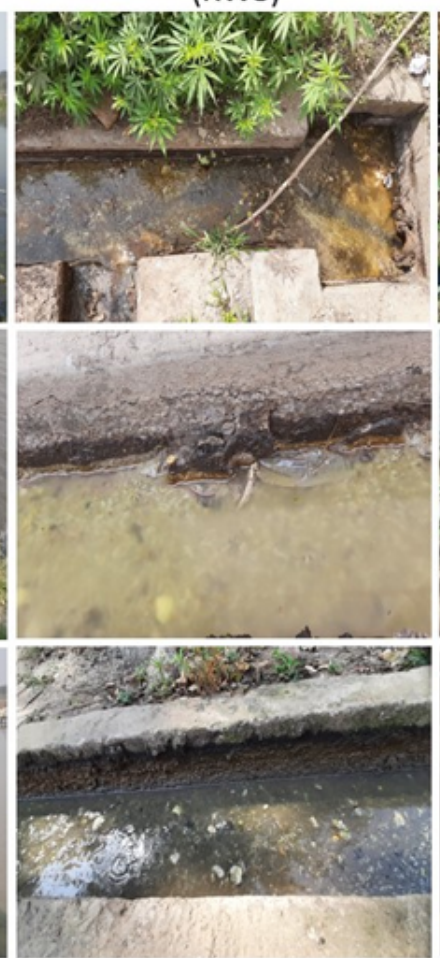

Mass bathing sites (MBS)
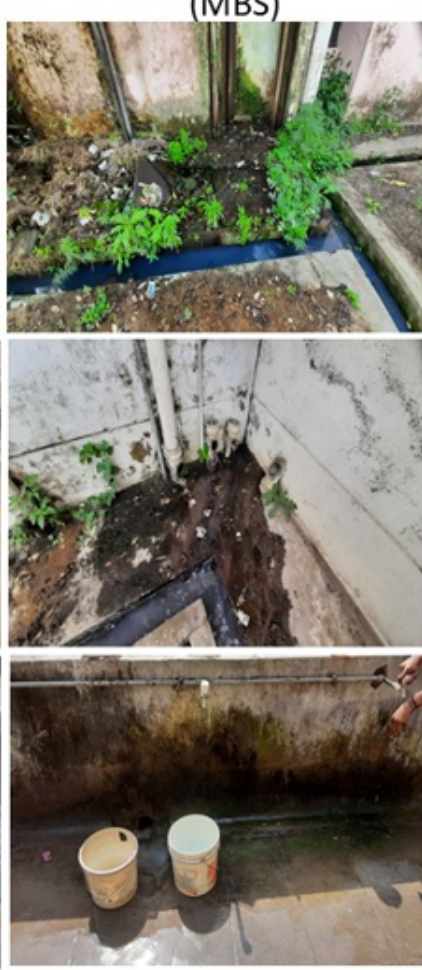

Sample collection, preparation and examination

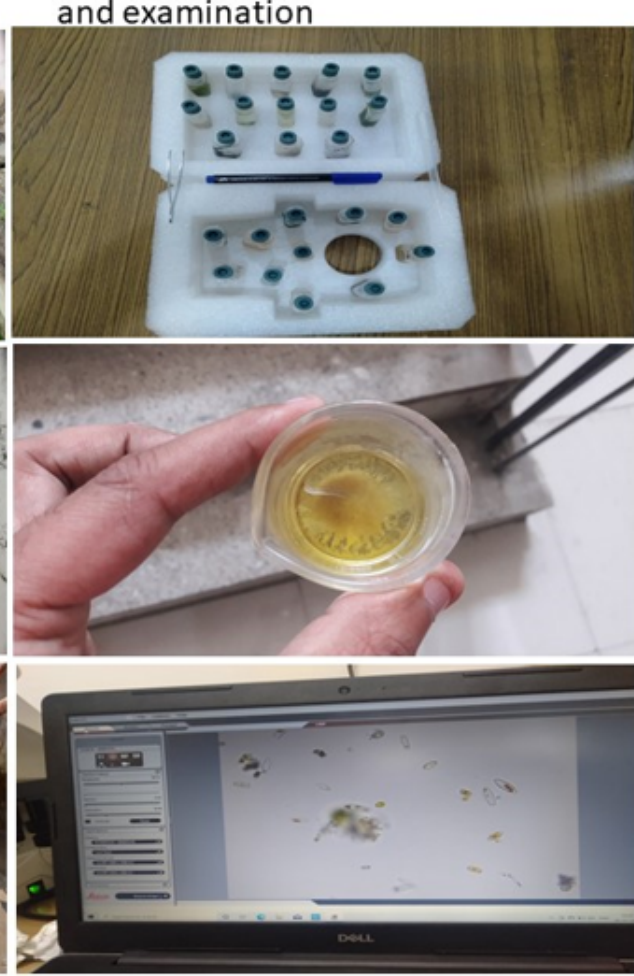

\section{Figure 2}

Photographic illustrations of polluted waste sites surveyed from the Moradabad and Bareilly districts of Uttar Pradesh, India. RWS sites are the riverine sites at the bank of Ramganga river in Moradabad. KWS and MBS sites (boy's and girl's hostel) are located in the MJP Rohilkhand University, Bareilly. All these sites bears long term legacy of organic pollution.

\section{Mass bathing sites \\ (MBS)}

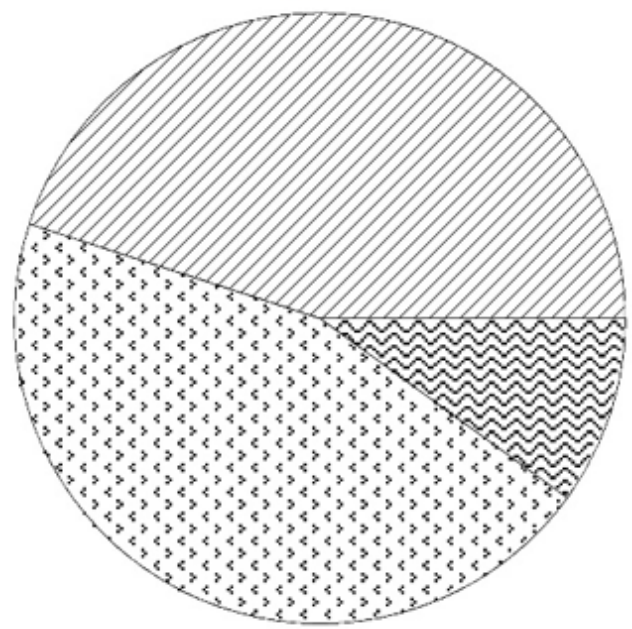

$\mathbb{Z} \quad$ Bacillariophyceae

\section{Riverine waste sites (RWS)}

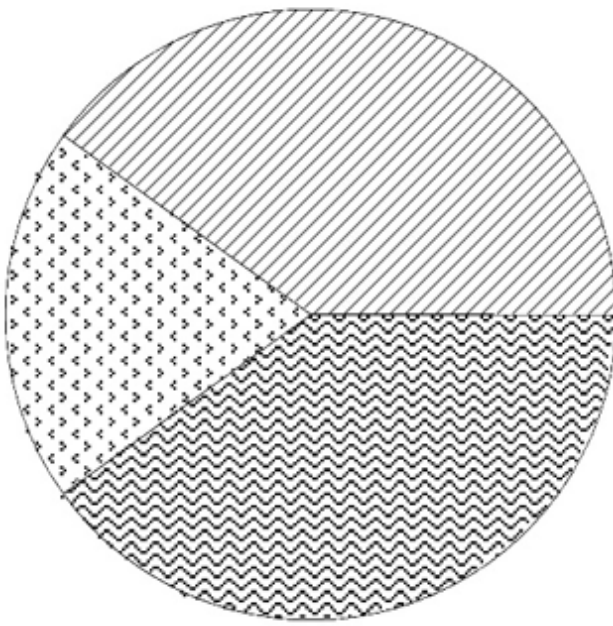

3. Chlorophyceae

\section{Kitchen waste sites (KWS)}

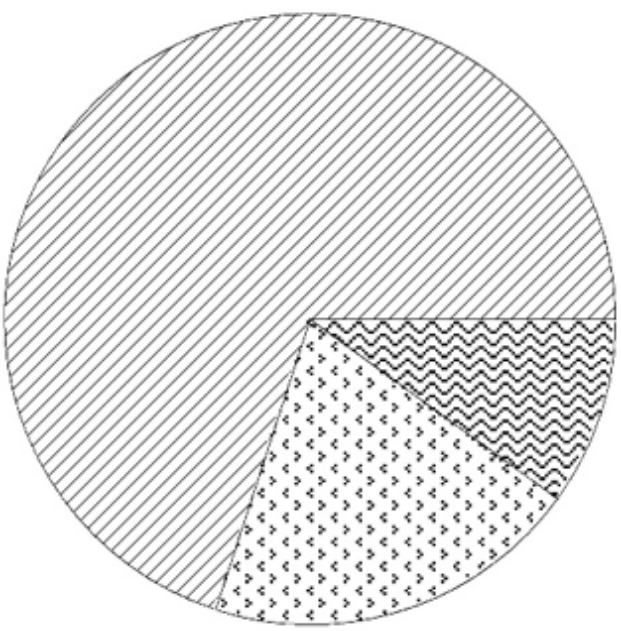

$\approx$ Euglenophyceae 


\section{Figure 3}

Community composition of different algal classes found in the periphytic algal

communities collected from the three surveyed areas.
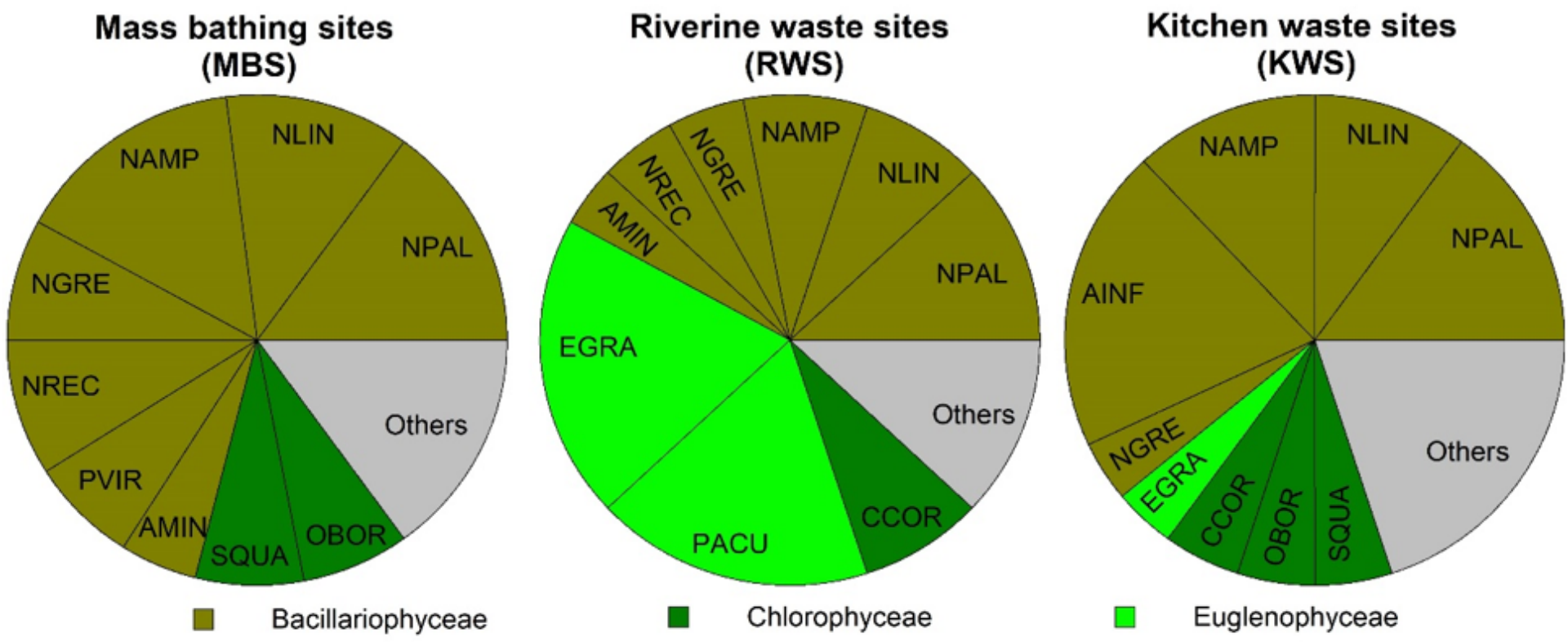

Figure 4

Community composition of dominant (relative abundance $>1 \%$ ) algal species found in three different waste sites in Moradabad and Bareilly, India. Abbreviations: NPAL-Nitzschia palea, NLIN-Nitzschia linearis, NAMP-Nitzschia amphibia, NGRE-Navicula gregaria, NREC-Navicula recens, PVIR-Pinnularia viridis, AMIN-Achnanthidium minutissimum, SQUD-Scenedesmus quadricauda, OBOR-Oocystis borgei, EGRA-Euglena gracilis, PACU-Phacus acuminatus, CCOR-Cosmarium corda and AINF-Achnanthes inflata. 


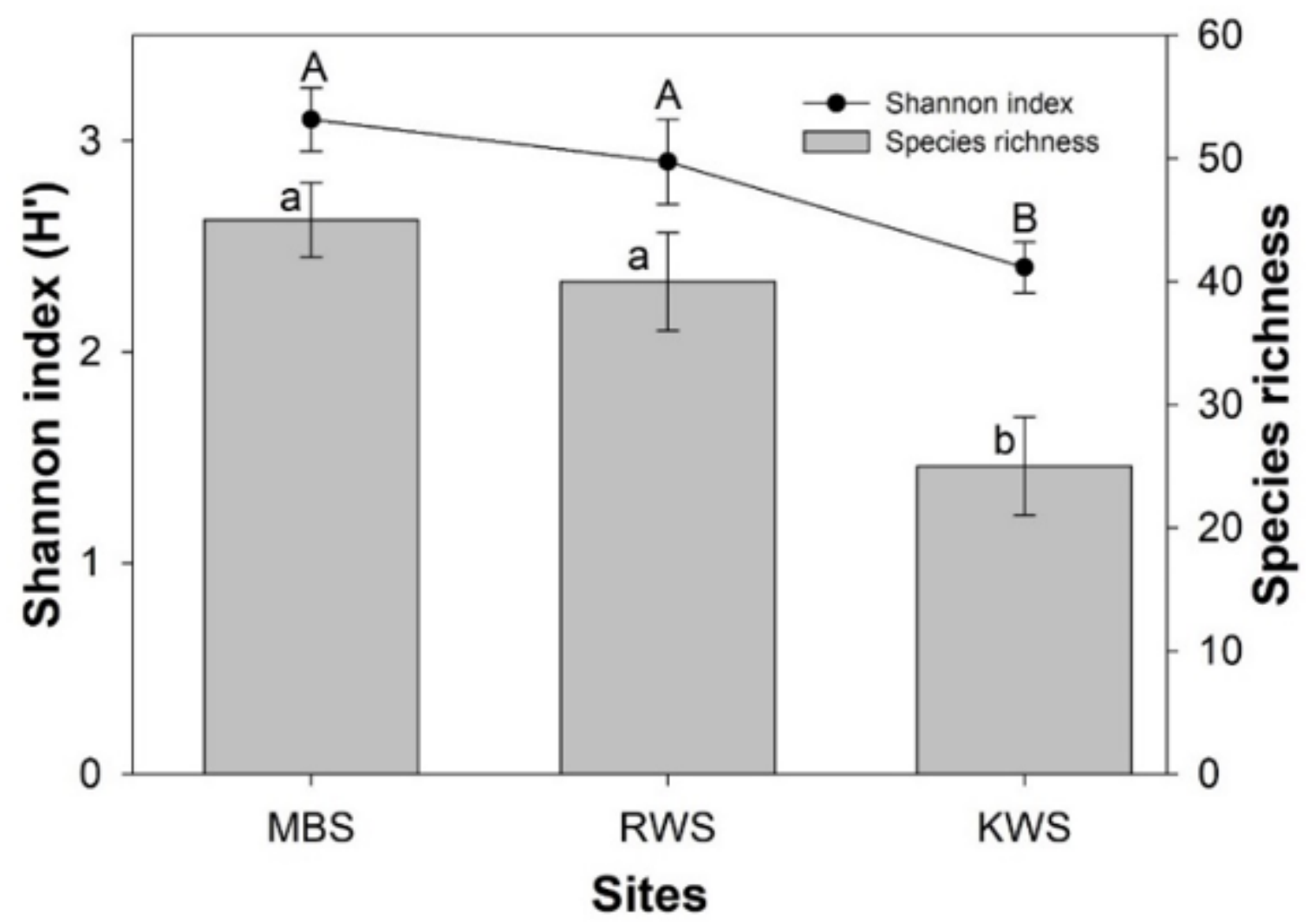

Figure 5

Shannon index $\left(\mathrm{H}^{\prime}\right)$ and species richness (mean $\pm \mathrm{SE}$ ) of periphytic algal communities collected from the three surveyed areas. Different letters above bars or data points from different sites indicate significant differences $(p<0.05$; Tukey's HSD test). 


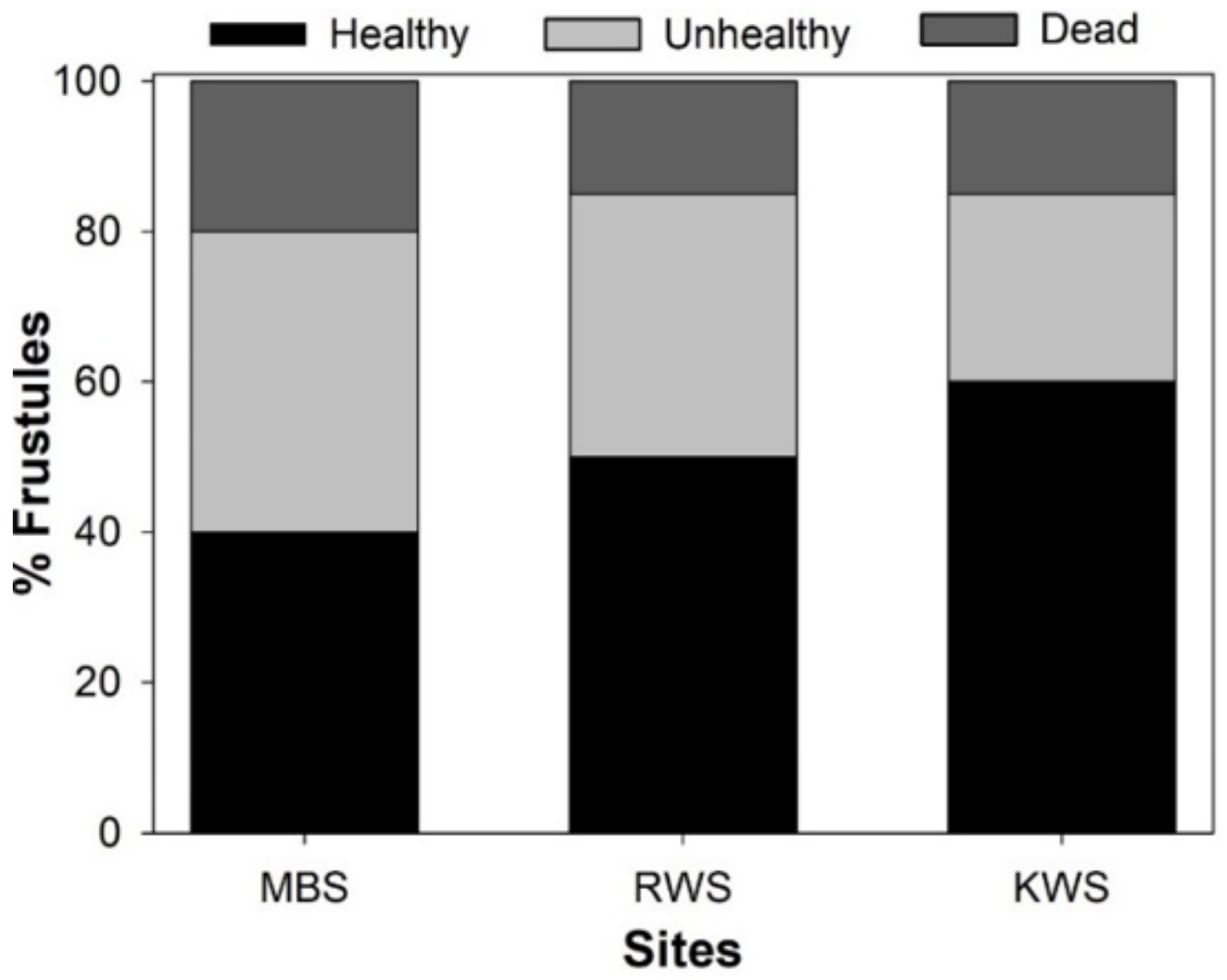

Figure 6

Health status (\% frustules) of diatom community collected from various waste sites of Moradabad and Bareilly, India. 

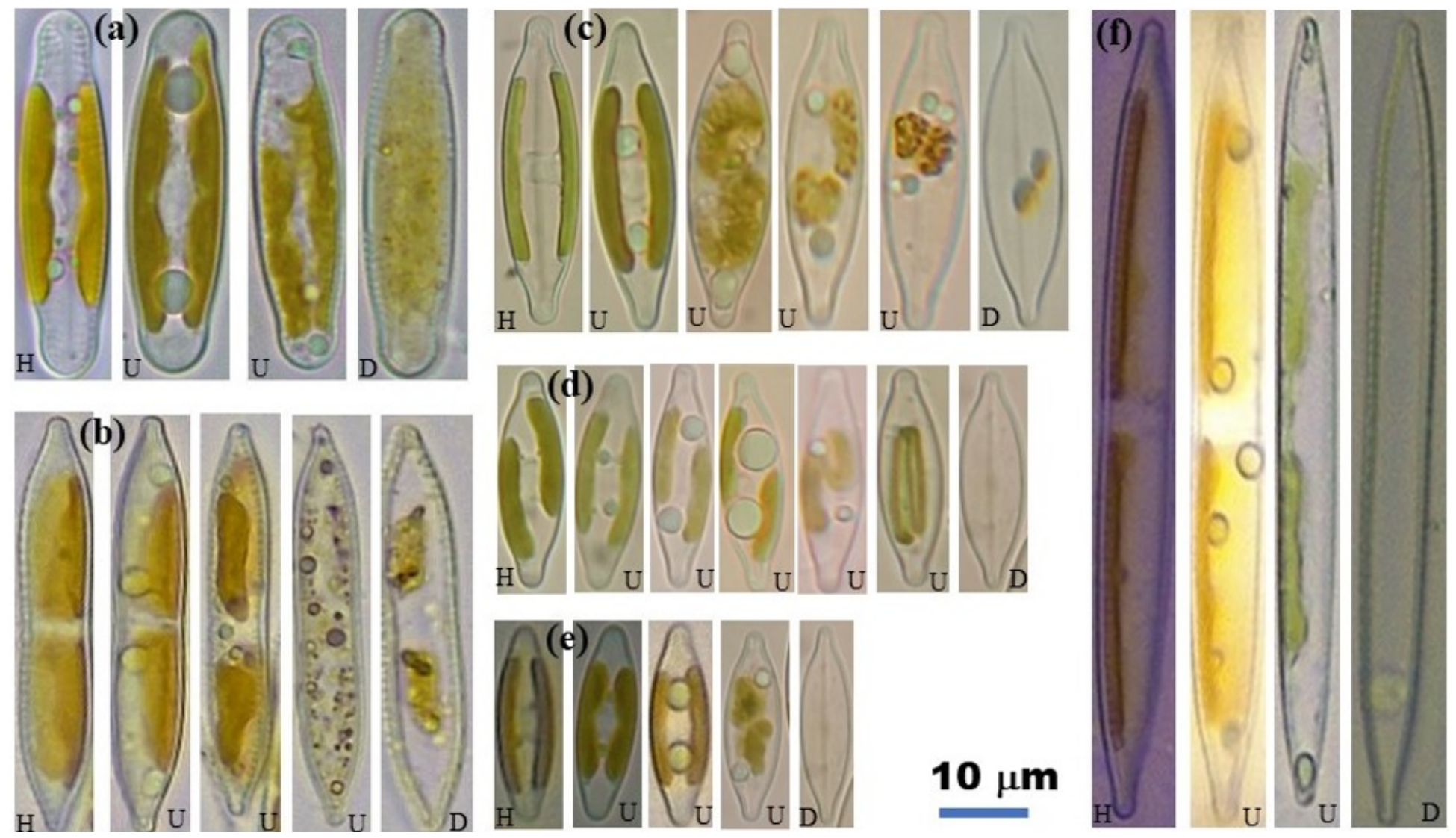

\section{Figure 7}

Photographic illustration of two indicators of diatom condition: diatom heath and the presence and size of lipid bodies. Each set of plates illustrates the range from Healthy $(H)$ to Unhealthy $(U)$ to Dead $(D)$ cells of different diatom species. Globular structures inside diatom cells show lipid bodies (LBs). Illustrated diatom species are: (a) Caloneis bacillum, (b) Nitzschia amphibia, (c) Navicula slesvicensis, (d) Navicula gregaria, (e) Navicula veneta and (f) Nitzschia linearis; all collected from the surveyed sites in the Moradabad and Bareilly districts of Uttar Pradesh, India. 

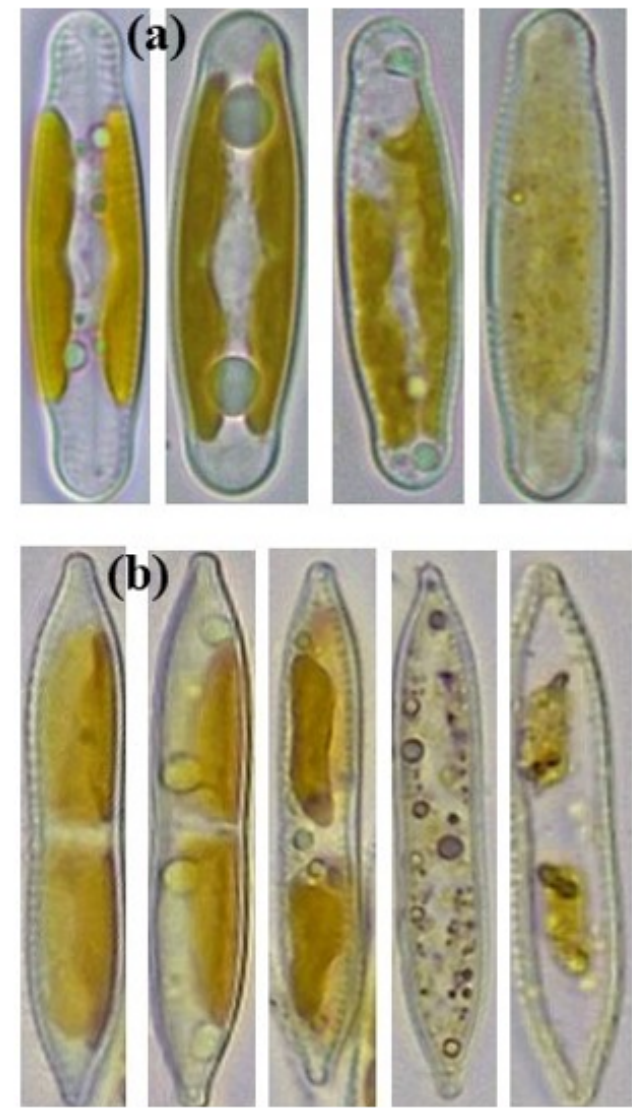

(b)

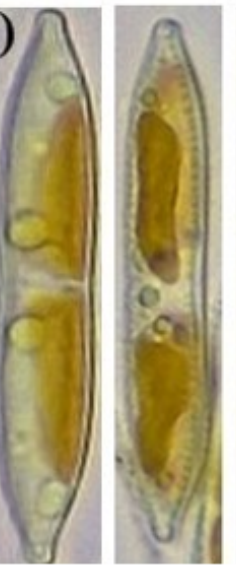

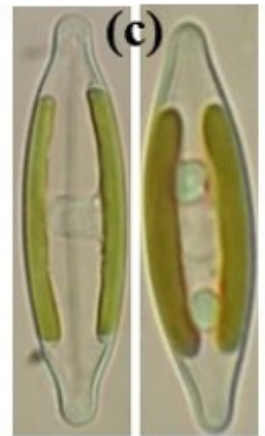
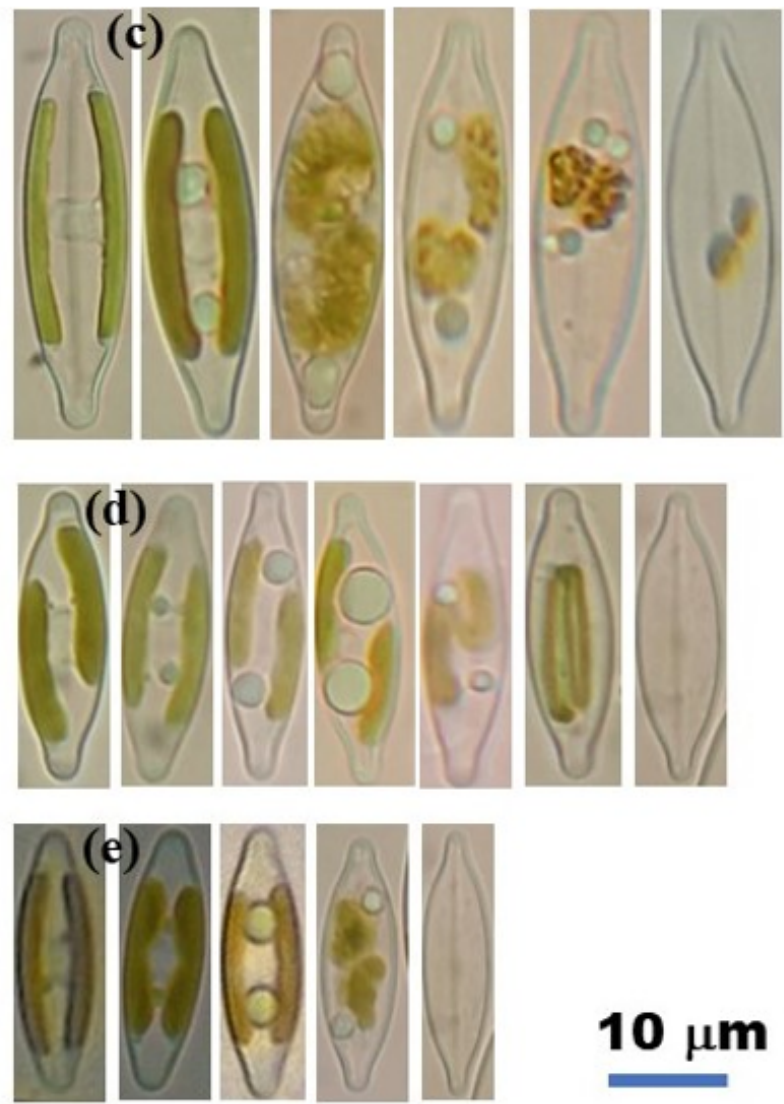
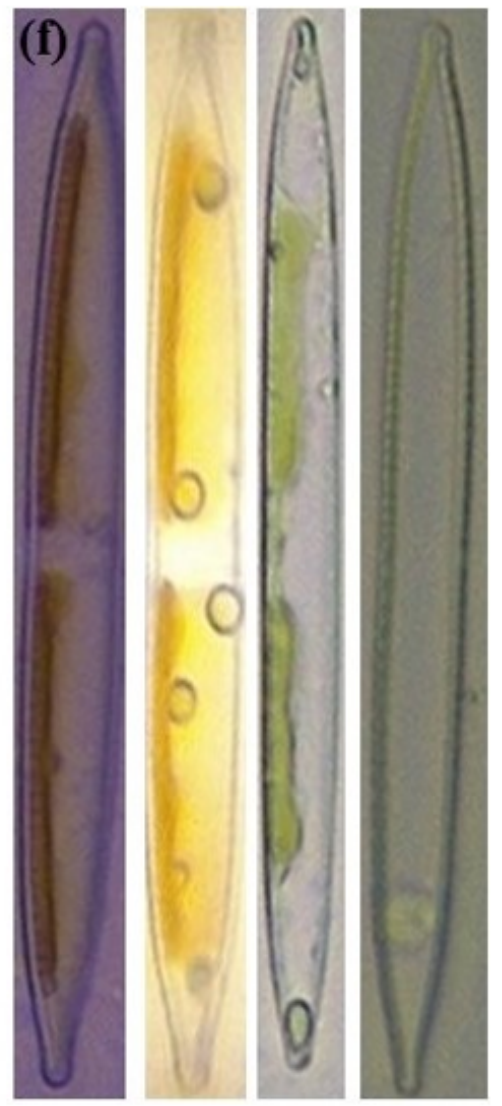

\section{Figure 8}

Morphological examination of lipid bodies (number and biovolume) and health status of different diatom species collected from different waste sites of Moradabad and Bareilly districts of Uttar Pradesh, India. Identified diatom species are: (a) Caloneis bacillum, (b) Nitzschia amphibia, (c) Navicula slesvicensis, (d) Navicula gregaria, (e) Navicula veneta and (f) Nitzschia linearis. Globular structures inside diatom cells represent lipid bodies (LBs). 


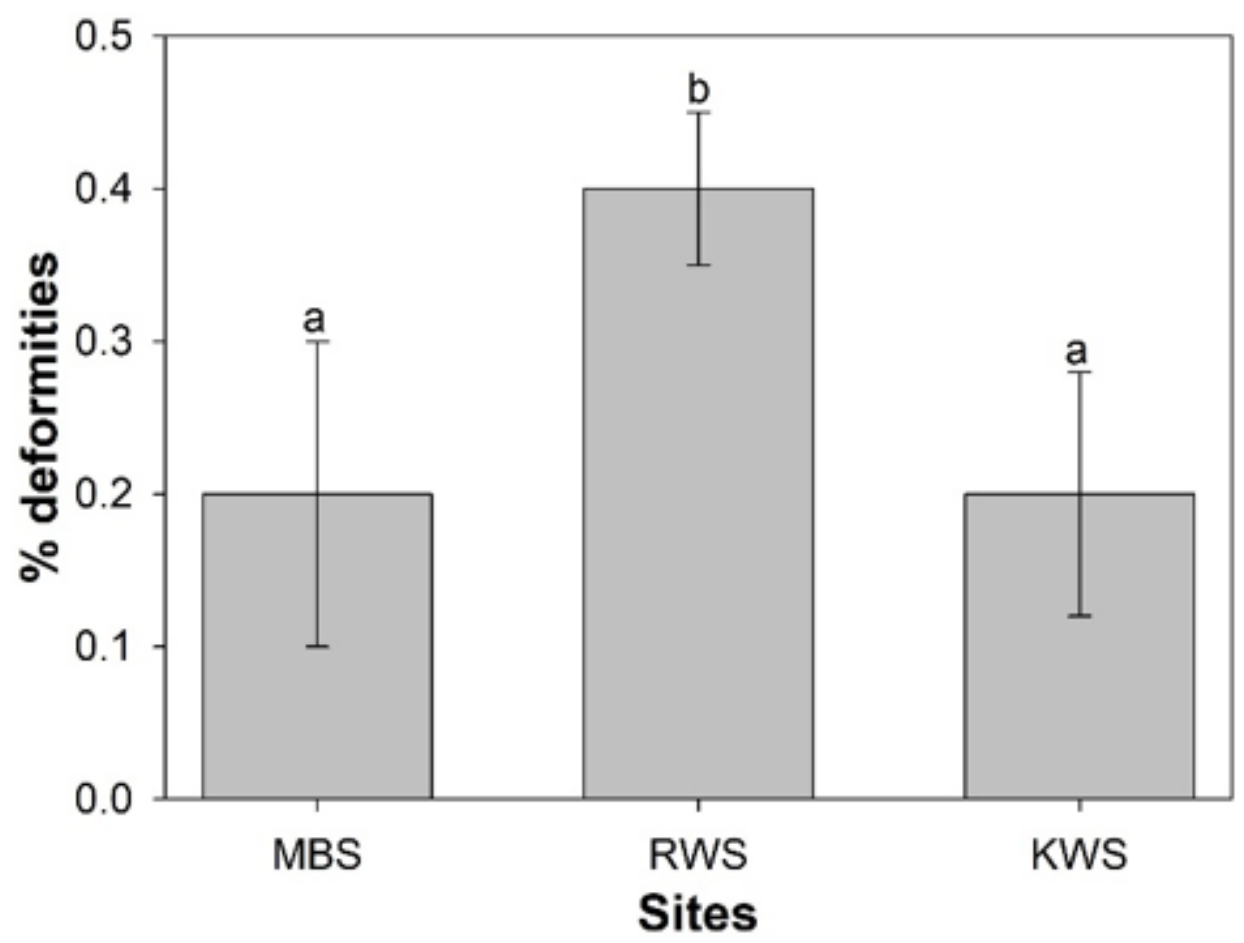

Figure 9

Percent deformities (mean $\pm \mathrm{SE}$ ) of the diatom frustules in the diatom communities collected from the three waste sites in Moradabad and Bareilly, India. Different letters over bars indicate significantly different percentages of deformity among sites ( $p<0.05$ : Tukey's HSD test).

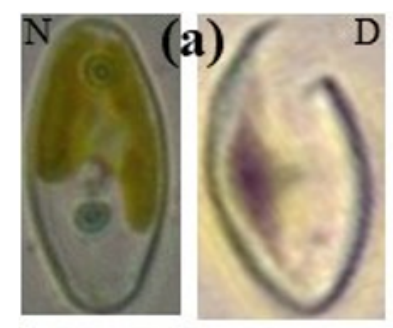

(b)
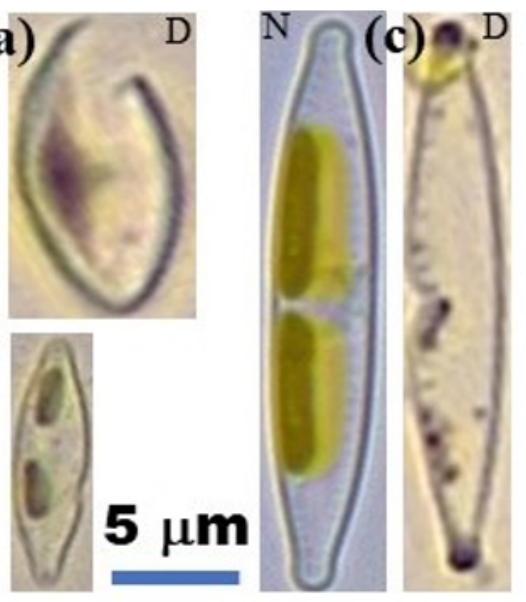
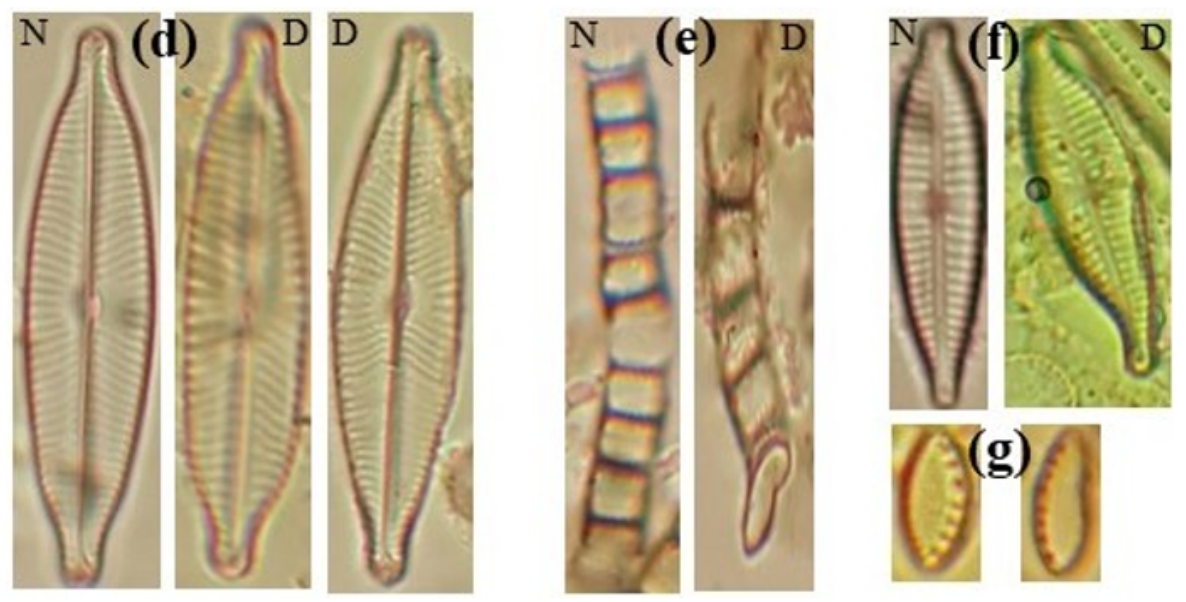

Figure 10

Morphological identification of normal (N) and deformed (D) frustules from different waste sites in the Moradabad and Bareilly districts of Uttar Pradesh, India. Identified diatom species are: (a) Navicula 
saprophila (live), (b) N. subminuscula (live), (c) Nitzschia palea (live), (d) Navicula slesvicensis, (e) Melosira distans, (f) Gomphonema parvulum and (g) Nitzschia minuta. 